Tijana SURLAN, $\mathrm{PhD}^{*}$

Constitutional Court of Serbia, Belgrade

UDK: $343.412: 340.132:: 351.74$

Originalni naučni rad Primljen: 27.01.2017. Datum prihvatanja: 13.02.2017.

\title{
Prohibition of torture: absolute or relative?
}

\begin{abstract}
Torture and other cruel, inhuman or degrading treatment or punishment is prohibited in absolute manner in all international legal acts regulating various forms or aspects of the mentioned ill-treatments. Although this prohibition communicates with all and presents obligationeergaomnes it is mainly directed toward law enforcement public officials. Thus from the overall scope of human rights, torture and other ill-treatments are those that are most usually undertaken by policemen. Policemen can find themselves in breach of the international human right norm, but even in the situation of perpetrating a crime. Prohibition of torture and other ill-treatments holds strong position in both international and national legal systems since it presents the very essence of a state. If a state allows its law enforcement officials to use force against individuals then power of the state itself is misused. Prohibition of torture is considered as an easy test on a democratic potential of a state andit also has strong political aspect, besides the legal one. Introductory points should lead a reader of this article into the pure legal analysis of very specific elements of torture and other cruel, inhuman or degrading treatment or punishment.
\end{abstract}

Keywords: torture, cruel, inhuman, degrading, Committee against Torture, European Court of Human Rights

\section{Introduction}

Prohibition of torture is one of the very few human rights norms that have been thoroughly stipulated in various sources of

*tijana.surlan@ustavni.sud.rs

БЕЗБЕДНОСТ 3/2016 
international law,creating various types of international norms. There have been even several decades of constant emergence of new regulations and rules on torture, cruel, inhuman and degrading treatment and punishment. Thus, it could be concluded that it is clear what should be understood under these terms. Or, quite to the contrary, the multiplicity of norms with the same subject-matter may have produced confusion.

There is a wide range of sources that participate in the corpus of anti-torture law. The Universal Declaration on Human Rights from 1948 is certainly the first legal act that defined terminology in the manner that is very well known and overwhelmingly accepted nowadays. In its Article 5 it is stipulated - No one shall be subjected to torture or to cruel, inhuman or degrading treatment or punishment. This approach is accepted in versions of all other legal acts,i.e. conventions. It is worth mentioning that the Universal Declaration, not-withstanding its legal nature of a decision of the international organization, has acquired significant influence on the whole human rights development (Brownlie, 2003). As the pioneer legal act that was adopted by states, it certainly has directed development that followed.

\section{Normative framework of the torture prohibition}

Diversity of legal acts stipulating torture asks for structuring of the overall normative framework(Milisavljević, 2016). First legal act in the field of human rightsafter the Universal Declaration that included prohibition of torture was the UN International Covenant on Civil and Political Rights from 1966. Its Article 7 repeated the Universal Declaration's wording, adding that in particular, no one shall be subjected without his free consent to medical or scientific experimentation`. Besides this norm, International Covenant arranged yet another one, quite similar norm. Article 10 stipulates treatment of persons deprived of liberty, generally requiring human treatment with respect for the inherent human dignity. ${ }^{1}$

\footnotetext{
${ }^{1}$ International Covenant on Civil and Political Rights, Article 10: "1. All persons deprived of their liberty shall be treated with humanity and with respect for the inherent dignity of the human person.
} 
On the universal level, prohibition of torture and other cruel, inhuman or degrading treatment or punishment was also recognized within the field of international humanitarian law (Than et al., 2003).The Geneva Conventions from 1949 and Additional Protocols from 1977 includedprohibition of torture and inhuman treatment. The Geneva Convention (I) on Wounded and Sick in Armed Forces in the Field stipulates (Article 12) that the wounded and the sick should be treated humanely inter alia and specifically prohibits torture. Similarly, the Geneva Convention (II) for the Amelioration of the Condition of Wounded, Sick and Shipwrecked Members of Armed Forces at Sea stipulates same obligations and prohibitions to the contracting parties. The Geneva Convention (III) Relative to the Treatment of Prisoners of War determined that during questioning of prisoners (article 17) 'no physical or mental torture, nor any other form of coercion, may be inflicted on prisoners of war to secure from them information on any kind whatever'. In addition Article 87 addresses penalties that could be rendered to prisoners, forbidding "any form of torture or cruelty". The wording of the Geneva Convention (IV) Relative to the Protection of Civilian Persons in Time of War is somewhat different. It stipulates general prohibition of coercion (Article 31) and prohibition of torture, within other prohibitions against protected persons, such as murder, mutilation, medical or scientific experiments, measures of brutality 'whether applied by civilian or military agents` (Article 32).Comparing with the human rights approach it is obvious that the Geneva Conventionsaddress the issue of torture in the spirit of the International Humanitarian Law, strictly within the subject matter of the precise treaty and in the context of an international armed conflict (Provost, 2002). On the other hand human rights treaties do create a general regime, addressing the state i.e. its organs that hold law enforcement

2.(a) Accused persons shall, save in exceptional circumstances, be segregated from convicted persons and shall be subject to separate treatment appropriate to their status as unconvicted persons;

(b) Accused juvenile persons shall be separated from adults and brought as speedily as possible for adjudication.

3. The penitentiary system shall comprise treatment of prisoners the essential aim of which shall be their reformation and social rehabilitation. Juvenile offenders shall be segregated from adults and be accorded treatment appropriate to their age and legal status." 
capacity, in diversity of situations where they can find themselves.The provision on internal armed conflicts, stipulated in the common Article 3 of the Geneva Convention, covers a wide range of situations that are neither war nor peace, prohibiting torture.

Additional Protocol I of 1977 stipulates fundamental guarantees (Article 75) and among them prohibition "at any time and in any place whatsoever, whether committed by civilian or by military agents" of inter alia "torture of all kinds, whether physical or mental". Similar approach could be found in the Additional Protocol II of 1977 in Article 4. This final approach complements with the characteristic of the prohibition of torture as the absolute norm that cannot be derogated in times of war, peace, revolution or coup.

In the light of comparison between human rights law and humanitarian law the issue of accountability emerges, where the grave breaches of both humanitarian law and human rights law can amount to international crimes, while human rights breaches do create international crimes but only those that can be committed in the context of peace as well. Definitions of grave breaches in all four Geneva Conventions stipulateinter alia "torture and inhuman treatment, including biological experiments, willfully causing great suffering or serious injury to body or health" (Geneva Convention I Article 50; Geneva Convention II - Article 51; Geneva Convention III - Article 130; Geneva Convention IV - Article 147). Crimes against humanity on the other hand do stipulate torture as actus reus but with no further directions whatsoever towardformal legal sources (Surlan, 2011: 318).

It is worth mentioning the customary torture norm as well, since it is understood that internationalization of torture as a primarily national law norm has emerged through the customary norm (Svanidze, 2009). In the project of the conceptualization of the customary lawgoverned by the International Committee of the Red Cross the rule 90 stipulates general prohibition of torture (Henckerts, Doswald-Beck, 2005). ${ }^{2}$

The most important anti-torture legal act is Convention against Torture and other Cruel, Inhuman or Degrading Treatment or

\footnotetext{
${ }^{2}$ Rule 90. Torture, cruel or inhuman treatment and outrages upon personal dignity, in particular humiliating and degrading treatment, are prohibited.
} 
Punishment from 1984 (Convention against Torture) (Krstic, 2004). The whole text of the Convention, from the very definition of torture through its specific elements is directed towards the problem of stateinflicted torture. Article 1 stipulates torture as "any act by which severe pain or suffering, whether physical or mental, is intentionally inflicted on a person for such purposes as obtaining from him or a third person information or a confession, punishing him for an act he or a third person has committed or is suspected of having committed, or intimidating or coercing him or a third person, or for any reason based on discrimination of any kind". Important part of the definition is request that "such pain or suffering is inflicted by or at the instigation of or with the consent or acquiescence of a public official or other person acting in an official capacity". It is additionallyclarified that it does not include pain or suffering arising from, inherent in or incidental to lawful sanctions.

The main purpose of this Convention was not to achieve an absolutely and overwhelmingly accepted definition of torture, but rather to oblige states-parties to arrange within their national legal systems measures to combat torture, especially within their criminal codes. ${ }^{3}$ Thus it is left open to states-parties to decide on precise definitions as long as the definitions covers three elements: (1) severe pain or suffering, whether physical or mental, (2) for purpose of obtaining information or confession, (3) by public official or other person acting in an official capacity. The definition itself, as it is obvious, does not offer elements to differ torture from cruel, inhuman or degrading treatment or punishment.

An important addition to the torture prohibition has been developed at the regional level. ${ }^{4}$ The Council of Europe has

\footnotetext{
${ }^{3}$ Definition of the torture in Article 1 of the Convention clearly states "For the purpose of this Convention..." On the other hand, there is a possibility for bodies and courts to lean on torture and other ill-treatments as they are expressed and elaborated in the convention on torture and other inhuman, degrading and cruel treatment or punishment. International Criminal Tribunal for Rwanda decided to embrace scope of torture and other ill-treatments as they are stipulated in the Torture Convention, Akayesu Case, Judgment, September 1998, par. 681.

4 Besides European human rights conventions, other continents/regions also developed their own human rights normative framework, such as Inter American Convention on Human Rights, Inter-American Convention to Prevent and Punish
} 
incorporated prohibition of torture in the European Convention for Protection of Human Rights and Fundamental Freedoms from 1950 (Dapcevic-Markovic, 2007). Article 3 shows a general prohibition approach, with no instructions whatsoever towards understanding of torture, inhuman, degrading and cruel treatment or punishment. The Council of Europe has arranged another legal act in the field of combating torture - the European Convention for the Prevention of Torture and Inhuman or Degrading Treatment or Punishment in 1987. The Convention does not offer definitions of torture and other forms of ill-treatment, since its main goal was to create the Committee for the Prevention of Torture and Inhuman or Degrading Treatment or Punishment. Its main jurisdiction is to "visit and examine the treatment of persons deprived of their liberty with a view to strengthening, if necessary, the protection of such persons from torture and from inhuman or degrading treatment or punishment".

Regional arrangement under the auspices of the Council of Europe thus has twofold protection for the prohibition of torture European Court for Human Rights and mentioned Committee. Both bodies contribute to the proper understanding and differentiation of torture and other forms of ill-treatments.

\section{Absolute prohibition of torture}

Main topic of this article is the legal character of the torture prohibition norm rather than mere description of the normative framework (Greer, 2015). There is a general opinion that torture is absolute international legal norm, jus cogensnorm and ergaomnesobligation, where no derogation whatsoever is allowed. ${ }^{5}$ It

Torture, African Charter on Human and People`s Rights; these will not be elaborated within this article.

${ }^{5}$ It is worth mentioning the General Comment no. 2 adopted by the Committee against Torture from 2 January 2008 considering the Implementation of Article 2 by State Parties. It reads: "This general comment addresses the three parts of article 2, each of which identifies distinct interrelated and essential principles that undergird the Convention's absolute prohibition against torture. Since the adoption of the Convention against Torture, the absolute and non-derogable character of this prohibition has become accepted as a matter of customary international law. The provisions of article 2 reinforce this peremptory jus cogensnorm against torture and constitute the foundation of the Committee's authority to implement effective means 
is a typical human rightist approach, governed by the very idea of humanity and necessity to provide protection of individual before an autocratic state. The status of jus cogensnorm as much as it is not defined or norms listed do have several formal aspects that should be fulfilled - existence of the potential jus cogens norm in the universal formal legal source, non-derogatory status and protection of fundamental values of the international community. ${ }^{6}$ It is undisputable that prohibition of torture fulfils all three formal requests. Primarily, all conventions that have been mentioned in the previous part of this article are universal conventions anddirectly stipulate that prohibition of torture is non-derogatory norm. Torture holds status of the norm that is contra bonos mores and as such representatively reflects fundamental values of the international community. On the other hand, theory does not offer such a unified view towards prohibition of torture status(Danilenko: 1991; Bekermen, 2005; Surlan: 2011: 135). Scholars involved in listing specific rights with recognized jus cogens status more often do not mention torture as such. It should be underlined though that status of jus cogens is given to the fundamental human rights, thus torture as a fundamental human right would be ipso facto jus cogens.

Jurisprudence of the International Criminal Tribunal for the former Yugoslavia does not indicate any doubt as to the character of prohibition of torture norm (Wet, 2004). In Furundzija case, within the elaboration on the torture in international law it is clearly stated that "prohibition of torture is a peremptory norm or jus cogens". Significance and absoluteness of this prohibition is illustrated from the aspect of this prohibition to expel, return or extradite a person to a state when "there are substantial grounds for believing that a person would be in danger of being subjected to torture". Extensive approach towards this prohibition has been expanded to another characteristic of it, the status of the ergaomnesobligation (Wet, 2004). ${ }^{9}$ Obligation

of prevention, including but not limited to those measures contained in the subsequent articles 3 to 16, in response to evolving threats, issues, and practices".

${ }^{6}$ TijanaSurlan, Zlocinprotivcovecnosti u medjunarodnomkrivicnompravu, Beograd, 2011, p. 135

${ }^{7}$ ICTY, Prosecutor v. AntoFurundzija, Judgement, 10 December 1998, par.144

${ }^{8}$ Ibid.

${ }^{9} \mathrm{Ibid}$, par.151-152 
owed towards all the members of international community is the quality attributed to human rights in general and in the overall picture it does support absoluteness of the prohibition of torture (Surlan, 2011).

Absoluteness of a right, obligation or prohibition reflects its strength in terms of application but it does not reflect its substance. As torture, cruel or inhuman behavior are not precisely defined in any of mentioned legal acts it is of the utmost importance to achieve common understanding of their meanings. It is not worth arguing on differentiations existing in the national legal systems. Contrary, elaborated and unified understanding on the level of the international law can provide unified stipulation at the level of national legal systems.

\section{Scope of meaning}

Elaboration of the scope of meaning should be started with the convention specialized for the torture and other cruel, inhuman or degrading treatment. There are three main aspects of torture and other forms of ill-treatment: 1) nature of the act, 2) purpose, 3) perpetrator. ${ }^{10}$ Thus, torture and other forms of ill-treatment should comprise infliction of severe pain or suffering, with the purpose of obtaining information or confession, undertaken by public official or person acting in official capacity. Convention on torture and other cruel, inhuman or degradingtreatment or punishment, does not offer any further description on forms of ill-treatment, such as what is to be understood under torture, cruel, inhuman, degrading conduct and how to distinguish them. There is another issue that should be clarified in general terms and that is relation between various prohibited treatments. The most important aspect of that relation is whether all forms of prohibited conducts hold all the same characteristics or not,

\footnotetext{
${ }^{10}$ Elements of torture could be divided into several groups; for example: 1) actus reus must result in severe physical or mental suffering, 2) the mens rea is determined by intentionally inflicting harm upon victim, 3) the act must have been committed for certain purposes, 4) the rationae personae is reserved for public officials or at least those persons acting in a public capacity, 5) torture excludes acts committed which are lawfully sanctioned, see Claire de Than, Edwin Shorts, International Criminal Law and Human Rights, Thomson, London, 2003, p.187.
} 
i.e. is inhuman, cruel or degrading treatment jus cogensnorm, ergaomnes obligation, and absolute non-derogative norm or do these attributes exclusively go with torture; and finally, why does it matter (Brownlie, 2003: 158)?

With the intent to thoroughly distinguish scope of the meaning of the used terms, it is useful to turn towards practice, i.e. application and interpretation of the norms.Bodies authorized to monitor application of prohibition of torture and other forms of prohibited conducts, as well as to consider or deliberate on individual complaints, have developed significant practice, which should behelpful for better understanding and overall compliance with the prohibition of torture. Human Rights Committeeinterprets the International Covenant on Civil and Political Rights, monitors states-parties and it is also authorized to consider individual complaints; the same can be stated for the Committee against Torture founded in the Convention on Torture and other cruel, inhuman or degrading treatment or punishment.

Judicial reasoning and deliberation on all specific aspects of torture and distinction between other forms of misconduct is thoroughly developed before the European Court of Human Rights and deserves attention (Popovic, 2016; Jaksic, 2006). Another judicial aspect of torture and other misconducts is elaborated in the jurisprudence of international criminal courts. Famous case in the matter of torture before the International Criminal Tribunal for the former Yugoslavia is Furundzija case just as the Akayesu case before the International Criminal Tribunal for Rwanda (Wet, 2004). The tribunals in both cases elaborated on the absolute character of the prohibition of torture, gave overall international law normative framework and elaborated on specific aspects of these cases. While the European Court of Human Rights does not deal with crime itself, international criminal courts do elaborate torture as actus reus within defined international crimes. Torture did not arise to a separate international crime, but nevertheless it is encompassed and can be encompassed in the future in various forms.

It is interesting to underline that contrary to the starting point of this article, articulated as the need to draw clear distinction between torture, degrading, cruel and inhuman conduct, the Human Rights Committee considers it is not "necessary to draw up a list of prohibited 
acts or to establish sharp distinctions between different kinds of punishment or treatment". ${ }^{11}$ Vice versa "the distinctions depend on the nature, purpose and severity of the treatment applied". ${ }^{12}$ The Committee against Torture had the opportunity to monitor states and to study thoroughly each national legal system in the matter of the prohibition of torture (McQuigg, 2011; Rid, 2007). Besides that, the Committee elaborates individual complaints in the matter of torture. For example, Serbia has been on the docket on several occasions. Generally, all these cases have been grounded on the silence of public prosecutor, urging Serbia to proceed on these specific cases. ${ }^{13}$

The importance of the differentiation between various misconducts does pertain until nowadays, and it could be concluded that until now, the work of all bodies authorisedto deal with torture in general in various arrangements provided enough experience to clarify the distinction between different misconducts. That task has been undertaken by the European Court of Human Rights as well. Its practice, lasting already for several decades, has produced impressive jurisprudence. One of the most significant cases in this subject matter is the case known as the Hooded Men, the case between Ireland and the United Kingdom (Rid, 2007; Popovic, 2016). The judgement, delivered in 1978 differentiated the famous "five techniques" hooding, wall-standing, loud noise, food and water deprivation, and sleep deprivation. ${ }^{14}$ Reasoning of the Court in this case provided the most influential differentiation between torture and inhuman, cruel and degrading treatment. While it would be expected easily to jump to conclusion that each kind of ill-treatment that is specific, using unusual, brutal techniques would fall under the category of torture, the Court has decided that distinction should not relyon the form of illtreatment, but on the consequences that it provokes on the victim.

11 UN Human Rights Committee, CCPR General Comment No. 20: Article 7 (Prohibition of Torture, or Other Cruel, Inhuman or Degrading Treatment or Punishment), 10 March 12, par. 4

${ }^{12} \mathrm{Ibid}$.

${ }^{13}$ The mentioned cases are: Committee on Torture, Complaint no.207/2002, Serbia and Montenegro, 29.11.2004; Committee on Torture, Complaint no.172/2000, Serbia and Montenegro, 28.11.2005; Committee on Torture, Complaint no. 171/2000, Serbia and Montenegro, 23.5.2005; Committee on Torture, Complaint no.174/2000, Serbia and Montenegro, 29.11.2005.

${ }^{14}$ European Court of Human Rights, Ireland v. United Kingdom, Judgment, par.96. 
Thus, the most important criteria for differentiation of ill-treatments are the intensity of suffering, whether physical or mental. Importance of the mentioned judgment rests especially on the fact that in this case the first decision was delivered by the European Commission, stating that described behaviour does form inhuman and degrading treatment but also torture. Contrary to this conclusion the Court elaborated that torture did not occur in the specific case, but only certain forms of inhuman and degrading treatment. The Court declared that "distinction derives principally from a difference in the intensity of the suffering inflicted". The Court considers in fact that, whilst on the one hand there is violence which is to be condemned both on moral grounds and also - in most cases - under the national laws of the Contracting States, but which does not fall within Article 3 (art. 3) of the Convention, it appears on the other hand that it was the intention that the Convention, with its distinction between "torture" and "cruel, inhuman or degrading treatment" to attach a special stigma to the first of these terms, which denotes deliberate inhuman treatment causing very serious and cruel suffering.Moreover, this seems to be the thinking lying behind Article 1 of Resolution 3452 (XXX) adopted by the General Assembly of the United Nations on 9 December 1975, which declares: "Torture constitutes an aggravated and deliberate form of cruel, inhuman or degrading treatment or punishment".Although the five techniques, applied in combination, undoubtedly amounted to inhuman and degrading treatment, and although their object was the extraction of confessions, the naming of others and/or information and although they were used systematically, they did not occasion suffering of the particular intensity and cruelty implied by the word torture as understood by the Court. ${ }^{15}$

Yet, there is no unique formula on the intensity of suffering. Elements that should be examined when deciding on the intensity are duration, sex, age and health of a victim, as well as methods of brutal conduct. Obviously it would be inappropriate to expect the list of actus reus that could fall under terms of torture and other ill-treatments. Thus, actus reus that rises to torture or other forms of ill-treatment can be recognised as such only by the consequences. The case that very well illustrates specificity of torture is the case of rape that was

${ }^{15}$ Ibid, par. 167. 
considered as torture- Aydin v. Turkey. ${ }^{16}$ The Court stated: “...the rape of a detainee by an official of the State must be considered to be an especially grave and abhorrent form of ill-treatment given the ease with which the offender can exploit the vulnerability and weakened resistance of his victim. Furthermore, rape leaves deep psychological scars (on the victim) which do not respond to the passage of time as quickly as other forms of physical and mental violence. ${ }^{, 17}$ Rape as actus reus of torture has been recognized by the Committee on Torture and Human Rights Council as well, in several occasions. ${ }^{18}$ On the other hand rape can be actus reus of other complex crimes. For example, both torture and rape do form actus reus within the complex international crime - crimes against humanity. In that version, rape does not form actus reus of torture but only of crimes against humanity. ${ }^{19}$

Distinction can be defined on each element. In general it is obvious that torture should be understood as the most severe mode of misconducts by public officials. Characteristics of torture could be defined in terms of duration, level of powerlessness of person, physical and mental effects of treatment or punishment.

On the other hand, inhuman treatment can occur outside of the custody or prison, even at the home of the victim. Inhuman behaviour can also be characterised as brutal, severe, provoking suffering. Distinction should be found in the severity of suffering that it provokes. In several cases the European Court discussed specific

\footnotetext{
${ }^{16}$ For the proper understanding of this specific case it is important to underline the context of this very example. Sukran Aydin was charged with using the Kurdish language while campaigning for elections; she wa not a criminal of any kind, thus the rape had different context and message. See: Claire McGlynn, Rape, Torture and European Convention on Human Rights, The International and Comparative Law Quarterly, Vol. 58, No. 3 (Jul., 2009), pp. 565-595

${ }^{17}$ European Court of Human Rights, Case of Sukran Aydin and others v. Turkey, Judgment 25 September 1997, par. 83.

${ }^{18}$ For example see: Committee against Torture, Concluding Observations on Czech Republic, UN Doc. CAT/C/CR/32/2, 2004, par. 5; Special Rapporteur on Torture, Report before the Human Rights Council, 15 January 2008, A/HRC/7/3, par. 36: "It is widely recognized, including by former Special Rapporteurs on torture and by regional jurisprudence, that rape constitutes torture when it is carried out by or at the instigation of or with the consent or acquiescence of public officials".

${ }^{19}$ International Criminal Tribunal for Rwanda, Akayesu Case, Judgment, September 1998, par.596-598.
} 
aspects of inhuman treatment and crystallised that even acts of destruction of a home can be regarded as an act of violence and deliberate destruction, which can provoke anguish and sufferingin a person. ${ }^{20}$ Similarly, the Court stated that threat ${ }^{21}$ to an individualwith torture "may constitute at least inhumantreatment". 22

Degrading treatment provokes less suffering and it is focused on provoking feelings such as fear, inferiority and humiliation. One of the significant cases for clarifying degrading treatment -Rainen v. Finland - adopted the criterionof the aim (Rid, 2007; Popovic, 2016). Thus, when deciding whether a certain conduct can fall under Article 3 of the European Convention of Human Rights, it is necessary to clarify whether such conduct aimed to degrade a person. ${ }^{23}$ One of the most important cases in the jurisprudence of the European Court of Human Rights for elaboration of degrading treatment is the case of Kudla v.

${ }^{20}$ See cases before the European Court of Human Rights: Selçuk and Asker v. Turkey, Dulas v. Turkey, Bilgin v. Turkey, 16 November

${ }^{21}$ One of the paragraphs from the Judgment in the Case Gafgen v. Germany is illustrative: "94. In assessing the treatment to which the applicant was subjected on 1 October 2002, the Court notes that it is uncontested between the parties that during the interrogation that morning, the applicant was threatened by detective officer E., on the instructions of the deputy chief of the Frankfurt am Main police, D., with intolerable pain if he refused to disclose J.'s whereabouts. The process, which would not leave any traces, was to be carried out by a police officer specially trained for that purpose, who was already on his way to the police station by helicopter. It was to be conducted under medical supervision. This was, indeed, established by the Frankfurt am Main Regional Court both in the criminal proceedings against the applicant (see paragraph 26 above) and in the criminal proceedings against the police officers (see paragraph 47 above). Furthermore, it is clear both from D.'s note for the police file (see paragraph 20 above) and from the Regional Court's finding in the criminal proceedings against $\mathrm{D}$. (see paragraph 47 above) that $\mathrm{D}$. intended, if necessary, to carry out that threat with the help of a "truth serum" and that the applicant had been warned that the execution of the threat was imminent.", European Court of Human Rights, Case Gafgen v. Germany, Judgment, 1 July 2010.

${ }_{22}$ European Court of Human Rights, Case Gafgen v. Germany, Judgment, 1 July 2010, par. 91

23 European Court of Human Rights, Case Rainen v. Finland, Judgment, 16 December 1997: "58. (...) Nor has the applicant made out his allegation that the handcuffing was aimed at debasing or humiliating him. According to the Ombudsman, whose findings the Court sees no reason to question, Corporal R. had acted in the belief that he complied with the relevant orders and the military education he had received (see paragraph 23 above). Finally, it has not been contended that the handcuffing had affected the applicant physically." 
Poland. In that case the Court underlined "a minimum level of severity". ${ }^{24}$ The Court stated: "The Court has considered ill-treatment to be "inhuman" because, inter alia, it was premeditated, was applied for hours at a stretch and caused either actual bodily injury or intense physical or mental suffering. Treatment has deemed to be "degrading" because it was such as to arouse in the victims feelings of fear, anguish and inferiority capable of humiliating and debasing them. On the other hand, the Court has consistently stressed that the suffering and humiliation involved must in any event go beyond that inevitable element of suffering or humiliation connected with a given form of legitimate treatment or punishment (...)." ${ }^{, 25}$ Threat itself is recognised as a method of provoking suffering and it is form of physiological or mental suffering. A significant case before the European Court of Human Rights clarifying significance of threat is Selmouni v. France.The victim in this case has been severely tortured by various methods, and only one of them was threat with syringe infected with HIV ${ }^{26}$ Threat, thus, can be considered as torture or any other form of ill-treatment, which will be determined by the intensity of suffering, as explained before. Exactly the same reasoning has been embraced by other bodies determining issues of torture such as the Committee for Torture or the Human Rights Committee. ${ }^{27}$

In the case Kraulaidis v. Lithuania quite another aspect of Article 3 of the European Convention of Human Rights appeared. Circumstances of the case show that in the car and motorcycle accident police did not display the required level of diligence when investigating the circumstances of the accident. ${ }^{28}$ As a result, the injured in this accident could not proceed before the court of law which

\footnotetext{
${ }^{24}$ European Court of Human Rights, Case of Kudla v. Poland, Judgment 26 October 2000, par.91

${ }^{25}$ Ibid, par.92

${ }^{26}$ European Court of Human Rights, Selmouni v. France, Judgment 2 July 1999, par. 24

${ }^{27}$ For example Committee against Torture, Concluding Observations on USA, UN Doc. CAT/C.USA/CO/2, par. 24, Committee on Civil and Political Rights, Njaru v Cameroon, Communication 1353/2005, 19 March 2007

${ }^{28}$ Cases covering application of Article 3 of the European Convention on Human Rights when acts are committed by private individuals were elaborated in Muta v. Ukraine and $\mathrm{O}$
} 
had finally led to the expiration of the statute of limitations. ${ }^{29}$ The Court found that "there has accordingly been a violation of Article 3 of the Convention under its procedural limb". ${ }^{30}$ The main ground for such a stand was the fact that the injury of the applicant resulted in his inability to walk. Thus the Court considered it as a severe consequence resulting from an inappropriate public official treatment. The Court underlined that "the Convention requires that the authorities conduct as effective official investigation into alleged ill-treatment, even if such treatment has been inflicted by private individuals (...) The procedural obligation under Article 3 of the Convention requires that any investigation should in principle be capable of leading to the establishment of the facts of the case and to the identification and punishment of those responsible for an offence. This is not an obligation of result, but one of means. The authorities must have taken the reasonable steps available to them to secure the evidence concerning the incident, such as by taking witness statements and gathering forensic evidence, and a requirement of promptness and reasonable expedition is implicit in this context (...).",31

The reasoning of the Court as surprisingly extended provoked four judges to issue Concurring Opinion. ${ }^{32}$ The main point of this Opinion was that in turning towards the procedural reading of human rights and freedoms they are trivialised thus losing their sharpness and telos. ${ }^{33}$ Reasoning of the four judges was grounded on determining the actus reus, while surprisingly they did not turn towards the lack of purpose which is a constitutive element of all kinds of ill-treatment. Extensive reasoning on application and interpretation has been welcomed also by the Human Rights Committee. In the General Comment 20 on Article 7of the International Covenant on Civil and Political Rights the Committee stated: "The aim of the provisions of article 7 of the International Covenant on Civil and Political Rights is to protect both the dignity and the physical and mental integrity of the

\footnotetext{
${ }^{29}$ European Court of Human Rights, Kraulaidis v. Lithuania, Judgment, 8 November 2016, par.63

${ }^{30}$ Ibid., par.64

${ }^{31}$ Ibid., par.57

${ }^{32}$ Ibid., Concurring Opinion of Judges Sajo, Tsotsoria, Wojtyczek and KucskoStadmayer

${ }^{33}$ Ibid., par. 7-12.
} 
individual. It is the duty of the State party to afford everyone protection through legislative and other measures as may be necessary against the acts prohibited by article 7 , whether inflicted by people acting in their official capacity, outside their official capacity or in a private capacity. The prohibition in article 7 is complemented by the positive requirements of article 10, paragraph 1 , of the Covenant, which stipulates that "All persons deprived of their liberty shall be treated with humanity and with respect for the inherent dignity of the human person" (Simovic et al. 2013).

Our intention to draw clearer lines between several similar misconducts has another important impediment. As through this article is obvious the European Court of Human Rights is the most influential when it comes to application and interpretation of human rights. Its position is less formal than real, since the burden of cases simply produces a huge amount of judgments and stands. On the other hand, the Court itself is inclined to interpret norms using techniques of evolutionary interpretation, which is directly stressed for the purpose of interpretation of Article 3 of the European Convention on Human Rights. In the case already cited,Selmouni v. France, the Court stated:"The Court has previously examined cases in which it concluded that there had been treatment which could only be described as torture. However, having regard to the fact that the Convention is a "living instrument which must be interpreted in the light of present-day conditions", the Court considers that certain acts which were classified in the past as "inhuman and degrading treatment" as opposed to "torture" could be classified differently in future. It takes the view that the increasingly high standard being required in the area of the protection of human rights and fundamental liberties correspondingly and inevitably requires greater firmness in assessing breaches of the fundamental values of democratic societies".

\section{Concluding remarks}

Is it possible for one norm to be absolute and relative at the same time? If we firmly support theory that no norm can be absolute in its full capacity and that each and every norm is limited with another norm, than we have the answer to the previous question (Bekerman, 2005; Farell, 2013; Greer, 2015). The answer thus would be that there 
is no absolute norm, and that each and every norm is limited with another norm (Rodley, 2007). If we try to apply this reasoning to the prohibition of torture and other ill-treatment we can focus on the socalled interrogational torture. Law enforcement officials can find themselves in a situation that a detainee has the knowledge important for the security of huge number of individuals, but is not willing to share it. Is a policeman allowed, in a situation as described, to use force against a detainee, forcefully collect necessary information and secure a number of potential victims? Theory has formed a doctrine on "interrogational torture in the ticking bomb scenario" (Brecher: 2007; Dershowitz:2008; Simeunovic-Patic, 2013). Although this idea can be seductive, it is not legal. Prohibition of torture and other forms of misconduct cannot be breached under any circumstances, but what can be applied in a situation as previously described is level of force that does not reach the threshold of prohibited ill-treatments. In general it is possible to state that absoluteness of torture prohibition is guaranteed for the level of severity that reaches the threshold of ill-treatments, but it does not mean that every kind of force is prohibited. Thus, "the ticking-time bomb" scenario is wrongly considered in terms of torture prohibition. Prohibition of torture is not limited with the hypothetical or real threat to the overall security; if a threat, whether hypothetical or real, exists, there is still a level of force or pressure that could be undertaken legally, that is legal.

Concluding the article it is possible to state that dualism absolute norm/relative norm should be viewed as twofold. One aspect of the dualism is legal, and it recognises the prohibition of torture and other forms of ill-treatment in general as an absolute norm. Yet, the relative aspect of prohibition arises when it comes to interpretation of prohibition and decision on what actus reus or what kind of consequence should emerge to declare a conduct as prohibited in terms of torture or other forms of ill-treatment. The other aspect of the dualism emerges when it comes to the concrete relation and purpose of force or pressure that an individual can be subjected to.The final conclusion teaches that legal quality of a norm should not be mixed up with the methods of interpretation. A norm can be absolute by it legal characteristics and yet seem as relative when it comes to means of interpretation. 


\section{References}

1. Bekerman O.Z. (2005), Torture: The Absolute Prohibition of a Relative Term: Does Everyone Know What Is in Room 101? The American Journal of Comparative Law, Vol. 53, No. 4 (Fall), pp. 743783.

2. Brecher B. (2007), Torture and the Ticking Bomb, Blackwell Publishing.

3. Brownlie I. (2003), Principles of Public International Law, Oxford University Press.

4. Danilenko G.M. (1991), International Jus Cogens: Issues of Law Making, European Journal of International Law, Vol.2, No.1.

5. Dapčević-Marković Lj. (2007), Dokumenti I mehanizmi Saveta Evrope u oblasti zabrane torture, nečovečnog ili ponižavajućeg postupanja, Bezbednost, Vol.49, No.1, pp.35-49.

6. Dershowitz A.M. (2008), Why Terrorism Works: Understanding the Threat, Responding to the Challenge, Yale University Press.

7. Greer S., (2015), Is the Prohibition against Torture, Cruel, Inhuman and Degrading Treatment Really 'Absolute' in International Human Rights Law? Human Rights Law Review, Vol.15, 2015, pp.101-137.

8. Farrell M. (2013), The Prohibition of Torture in Exceptional Circumstances, Cambridge University Press.

9. Henckaerts J.M., Doswald-Beck L. (2005), Customary International Humanitarian Law, International Committee of the Red Cross, Cambridge.

10. Jakšić, A. (2006) Evropska konvencija o ljudskim pravima - komentar. Beograd.

11. Krstic I. (2004), Zabrana mис̌enja I drugi hoblika zlostavljanja u medjunarodnom pravu - magistarskateza, Beograd.

12. McQuigg R. (2011), How Effective is the United Nations Committee Against Torture?,European Journal of International Law, Vol.22, Issue 3, pp.813-828.

13. Milisavljević B. (2016), Međunarodno običajno pravo, Beograd.

14. Popovic D. (2016), Evropsko pravo ljudskih prava, Beograd.

15. Provost R. (2002), International Human Rights and Humanitarian Law, Cambridge University Press.

16. Rid K. (2007), Evropska konvencija o ljudskim pravima - vodič za praktičare, knjiga 2, Beograd. 
17. Rodley N.S. (2007), The Prohibition of Torture: Absolute Means Absolute, Wolfgang Kaleck, Michael Ratner, Tobias Singelnstein, Peter Weiss (eds.), International Prosecution of Human Rights Crimes, Springer, pp.184-200.

18. Simeunovic Patic B. (2013), Teorija situacijskog postupanja: postavke, značaji perspective, NBP- Journal of Criminalistics and Law, No.2, pp.93-106.

19. Simović D., Avramović D., Zekavica R. (2013), Ljudska prava, Kriminalističko-policijska akademija, Beograd.

20. Surlan T. (2011), Zločin protiv čovečnosti u međunarodnom krivičnom pravu, Beograd.

21. Svanidze E. (2009), The European Convention for the Prevention of Torture, in: GundmundurAlfredsson, Jonas Grimheden, Bertrand G. Ramcharan, Alfred Zayas (eds.), International Rights Monitoring Mechanisms: Essays in Honour of Jakob Th. Moller, MartinusNijhoff Publishers.

22. Than C., Shorts E., (2003), International Criminal Law and Human Rights, Thomson Sweet and Maxwell, London.

23. Wet E. (2004), The Prohibition of Torture as an International Norm of Jus Cogens and its Implications for National and Customary Law, European Journal of International Law, Vol.15, No.1.

\section{Забрана тортуре: апсолутна или релативна норма?}

Резиме: Насловљени рад посвећен је разматрању варијација забране тортуре и осталих нехуманих, окрутиних и деградирајућих понашања или кажњавања. Забрана припада областима међународних људских права и међународног хуманитарног права, а санкционисана је како у општем, тако и у међународном кривичном праву. Ради се заправо о норми која, иако је стимулисана у односу на све појединце, суштински је забрана коју по правилу крше полицајци. Како је у самом опису ових радњи и нихова сврха, а то је добијање информачије или признања, утолико се јасно да је она превасходно у надлежности полиције. Радње које се заједнички спомиюу у низу, у готово свим изворима права који се баве овом темом, су подједнако блиске и сличне, као и различите. Њихово разликовање, те градација од изузетне је важности јер омогућава одвајање оних радњи које могу бити 
сличне, али ипак не потпадају у свим својим елементима под ову забрану. Забрана је по свом правном карактеру апсолутна, али може добити карактер релативности у два случаја. Један случај је када одвојимо радюу која је дозвољена од недозвољене. Други је када јасно направимо разлику између описивања карактеристика норме и примену и тумачене норме.

Кључне речи: тортура, окрутно, нехумано, деградирајуће, Комитет за борбу против тортуре, Европски суд за људска права. 